Prepared in cooperation with the

Massachusetts Department of Environmental Protection

\title{
Development of Simulated Groundwater-Contributing Areas to Selected Streams, Ponds, Coastal Water Bodies, and Production Wells in the Plymouth-Carver Region and Cape Cod, Massachusetts
}

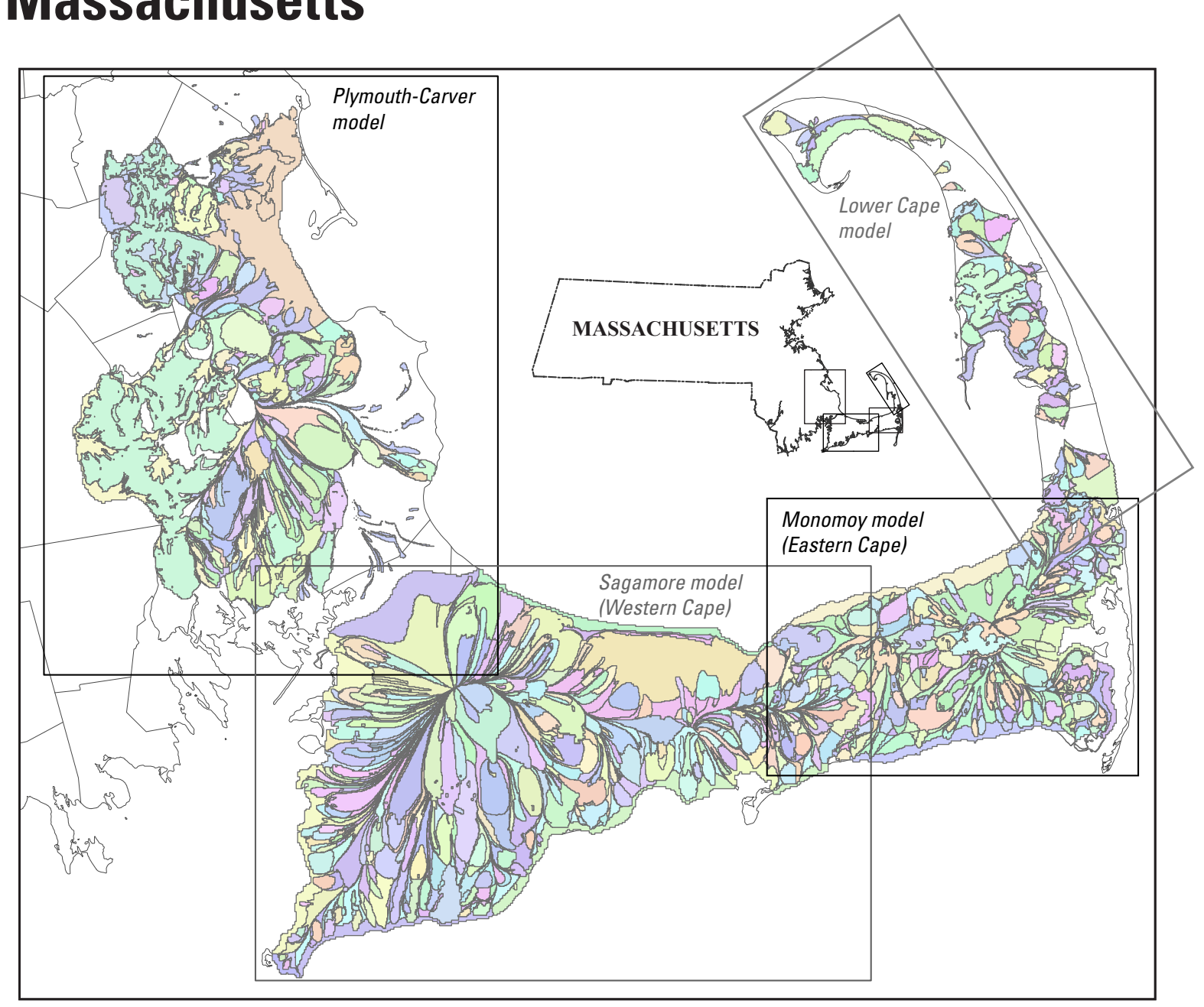

Data Series 1074 
Cover. Simulated groundwater-contributing areas for the Plymouth-Carver region and Cape Cod in southeastern Massachusetts. 


\section{Development of Simulated Groundwater- Contributing Areas to Selected Streams, Ponds, Coastal Water Bodies, and Production Wells in the Plymouth-Carver Region and Cape Cod, Massachusetts}

By Carl S. Carlson, John P. Masterson, Donald A. Walter, and Jeffrey R. Barbaro

Prepared in cooperation with the

Massachusetts Department of Environmental Protection

Data Series 1074 


\title{
U.S. Department of the Interior \\ RYAN K. ZINKE, Secretary
}

\section{U.S. Geological Survey William H. Werkheiser, Deputy Director exercising the authority of the Director}

\author{
U.S. Geological Survey, Reston, Virginia: 2017
}

For more information on the USGS - the Federal source for science about the Earth, its natural and living resources, natural hazards, and the environment-visit https://www.usgs.gov or call 1-888-ASK-USGS.

For an overview of USGS information products, including maps, imagery, and publications, visit https://store.usgs.gov.

Any use of trade, firm, or product names is for descriptive purposes only and does not imply endorsement by the U.S. Government.

Although this information product, for the most part, is in the public domain, it also may contain copyrighted materials as noted in the text. Permission to reproduce copyrighted items must be secured from the copyright owner.

Suggested citation:

Carlson, C.S., Masterson, J.P., Walter, D.A., and Barbaro, J.R., 2017, Development of simulated groundwater-contributing areas to selected streams, ponds, coastal water bodies, and production wells in the Plymouth-Carver region and Cape Cod, Massachusetts: U.S. Geological Survey Data Series 1074, 17 p., https://doi.org/10.3133/ds1074.

ISSN 2327-638X (online) 


\section{Contents}

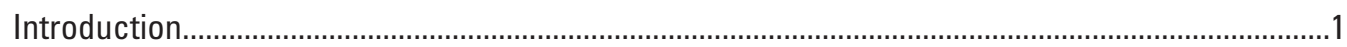

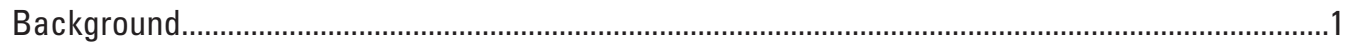

Groundwater-Flow Models .............................................................................................

Development Of Groundwater-Contributing Areas ...............................................................

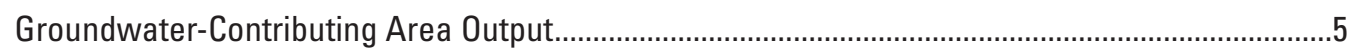

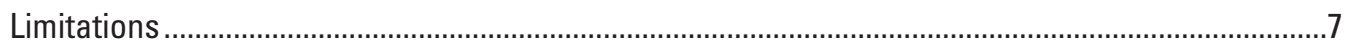

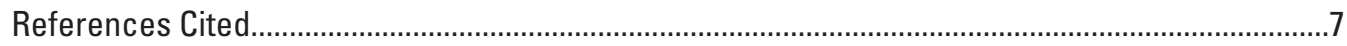

Appendix 1. Conversion Process from Original Electronic Format Files to Shapefiles......................9

\section{Figures}

1. Simulated groundwater-contributing areas for the Plymouth-Carver region and Cape Cod in southeastern Massachusetts ..........................................................................2

2. Groundwater-contributing area to a production well in a simplified hypothetical groundwater system .................................................................................................

3. Groundwater-contributing areas to production wells, ponds, and coastal water bodies within the Popponesset Bay watershed ................................................................

\section{Table}

1. Directory structure for simulated groundwater-contributing areas in Carlson and others (2017), Plymouth-Carver Region and Cape Cod, Massachusetts 


\section{Datum}

Vertical coordinate information is referenced to the North American Vertical Datum of 1988 (NAVD 88).

Horizontal coordinate information is referenced to the North American Datum of 1983 (NAD 83).

\section{Abbreviations}

$\begin{array}{ll}\text { GIS } & \text { geographic information system } \\ \text { MassDEP } & \text { Massachusetts Department of Environmental Protection } \\ \text { MEP } & \text { Massachusetts Estuaries Project } \\ \text { SMAST } & \text { Massachusetts School for Marine Science and Technology } \\ \text { USGS } & \text { U.S. Geological Survey }\end{array}$




\title{
Development of Simulated Groundwater-Contributing Areas to Selected Streams, Ponds, Coastal Water Bodies, and Production Wells in the Plymouth-Carver Region and Cape Cod, Massachusetts
}

\author{
By Carl S. Carlson, John P. Masterson, Donald A. Walter, and Jeffrey R. Barbaro
}

\section{Introduction}

The U.S. Geological Survey (USGS), in support of the Massachusetts Estuaries Project (MEP), delineated groundwater-contributing areas to various hydrologic receptors including ponds, streams, and coastal water bodies throughout southeastern Massachusetts, including portions of the Plymouth-Carver aquifer system and all of Cape Cod. These contributing areas were delineated over a 6-year period from 2003 through 2008 by using previously published regional USGS groundwater-flow models for the Plymouth-Carver region (Masterson and others, 2009), the Sagamore (western) and Monomoy (eastern) flow lenses of Cape Cod (Walter and Whealan, 2005), and lower Cape Cod (Masterson, 2004). The original USGS groundwater-contributing areas were subsequently revised in some locations by the MEP to remove modeling artifacts or to make the contributing areas more consistent with site-specific hydrologic conditions without further USGS review. This report describes the process used to create the USGS groundwater-contributing areas and provides these model results in their original format in a single, publicly accessible publication.

\section{Background}

The coastal waters of southeastern Massachusetts have been degraded by excess nitrogen inputs associated with residential and commercial development in the groundwater-contributing areas that discharge to these waters. The excess nitrogen, originating mainly from anthropogenic sources such as wastewater and fertilizer, causes eutrophication, which results in fish kills, diminished shellfisheries, excessive algal growth, and loss of other marine habitat. Because coastal waters are important economic and recreational resources, protection and restoration of coastal waters are important environmental and economic goals for the region.
In response to concerns over degraded coastal water quality, the Massachusetts Department of Environmental Protection (MassDEP), in collaboration with the School for Marine Science and Technology (SMAST) at the University of Massachusetts-Dartmouth, established the MEP in 2001. The MEP collected data to evaluate water-quality conditions in coastal water bodies and developed models that link nitrogen loading in a watershed to coastal water quality. The MassDEP used the results of these studies to develop total maximum daily loads for a large number of estuaries and embayments and inform wastewater management and nutrient reduction efforts in southeastern Massachusetts.

Between 2003 and 2008, the USGS assisted MassDEP with the MEP investigations by delineating groundwatercontributing areas (also referred to by local stakeholders as groundwater watersheds) to ponds, streams, coastal water bodies, and production wells in the Plymouth-Carver region and on Cape Cod in southeastern Massachusetts (fig. 1).

The USGS provided simulated groundwater-contributing areas to the MEP during a 6-year period (2003-8) that were produced from four groundwater models that were documented in three separate reports. The Cape Cod groundwatercontributing areas were provided to the MEP from 2003 to 2004. The three Cape Cod models are documented in Walter and Whealan (2005) and Masterson (2004). The PlymouthCarver region groundwater-contributing areas were provided to MEP in 2008; the model used for these delineations is documented in Masterson and others (2009).

The groundwater-contributing areas that were delineated as part of these investigations are integral to the ongoing watershed-based permitting program being implemented by the MassDEP throughout southeastern Massachusetts. Groundwater-contributing areas were delineated for various hydrologic receptors that included coastal water bodies, ponds and streams upgradient of coastal water bodies, and production wells.

The original USGS groundwater-contributing areas were delineated with existing groundwater-flow models and subsequently revised in some locations by the MEP to remove 


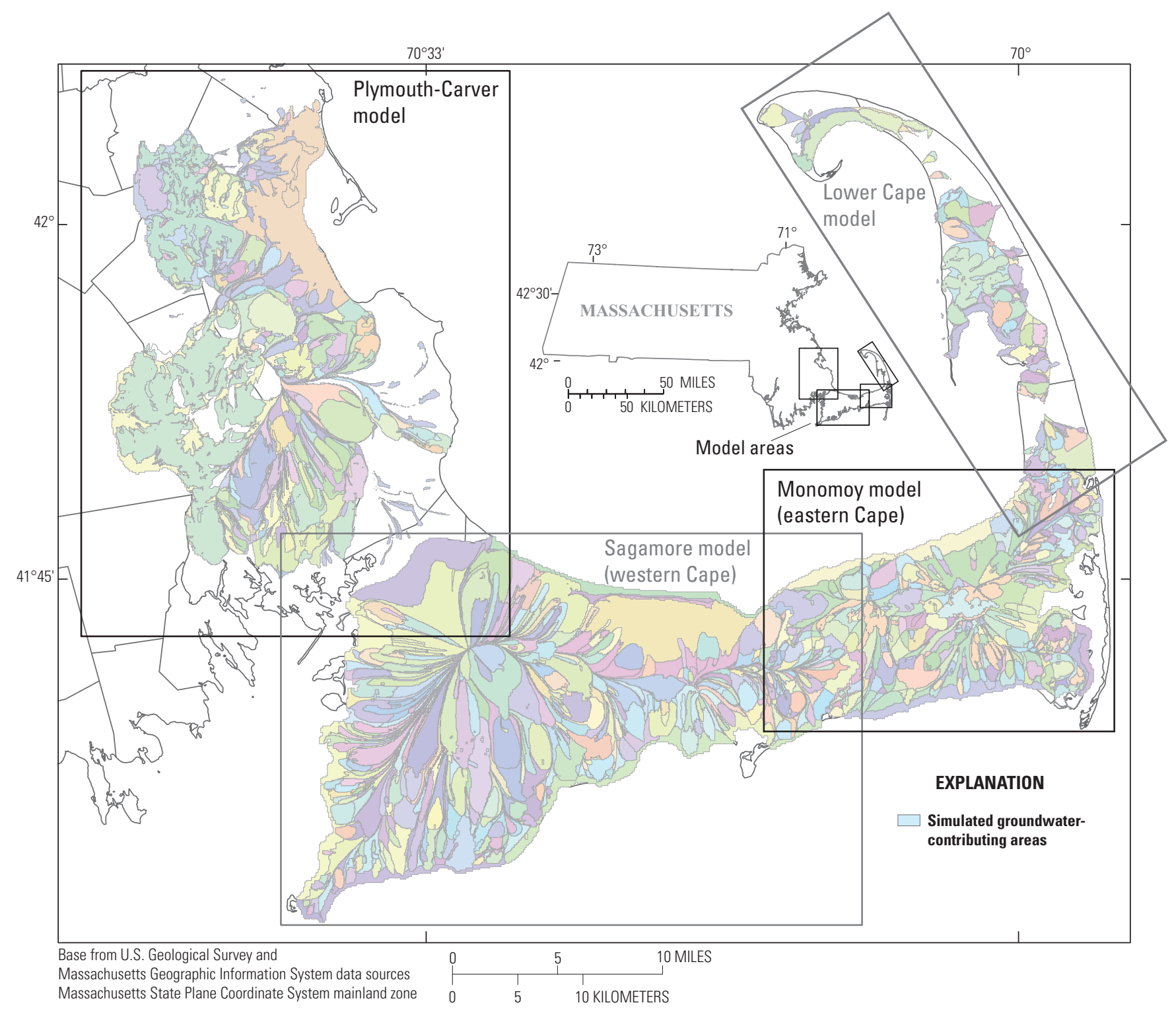

Figure 1. Simulated groundwater-contributing areas for the Plymouth-Carver region and Cape Cod in southeastern Massachusetts.

modeling artifacts — such as portions of the elongated tail of a contributing area upgradient and separate from its main body, which may or may not contribute recharge to that particular receiving water body - or to make the watersheds more consistent with site-specific hydrologic features or streamflow data collected by SMAST. Because the original, unmodified groundwater-contributing areas were not previously published by USGS, individual geographic information system (GIS) shapefiles of the simulated groundwater-contributing areas and an ArcMap project to view the shapefiles are included in the companion data release (Carlson and others, 2017) to this report. Publication of these groundwater-contributing areas, and the methodology used to delineate them, will benefit stakeholders involved in ongoing wastewater management activities in southeastern Massachusetts.

\section{Groundwater-Flow Models}

The three-dimensional numerical models used to delineate groundwater-contributing areas to ponds, streams, coastal water bodies, and production wells (fig. 1) for the PlymouthCarver region, the Sagamore (western) and Monomoy (eastern) flow lenses of Cape Cod, and lower Cape Cod are fully documented in Masterson and others (2009), Walter and Whealan (2005), and Masterson (2004), respectively. These models are based on the USGS finite-difference numerical code MODFLOW (Harbaugh and others, 2000; Harbaugh, 2005). The USGS particle-tracking program MODPATH (Pollock, 1994) was used in conjunction with groundwater heads and flows calculated by MODFLOW to determine the initial locations of water particles that discharge to ponds, streams, 
A. Cross-sectional view

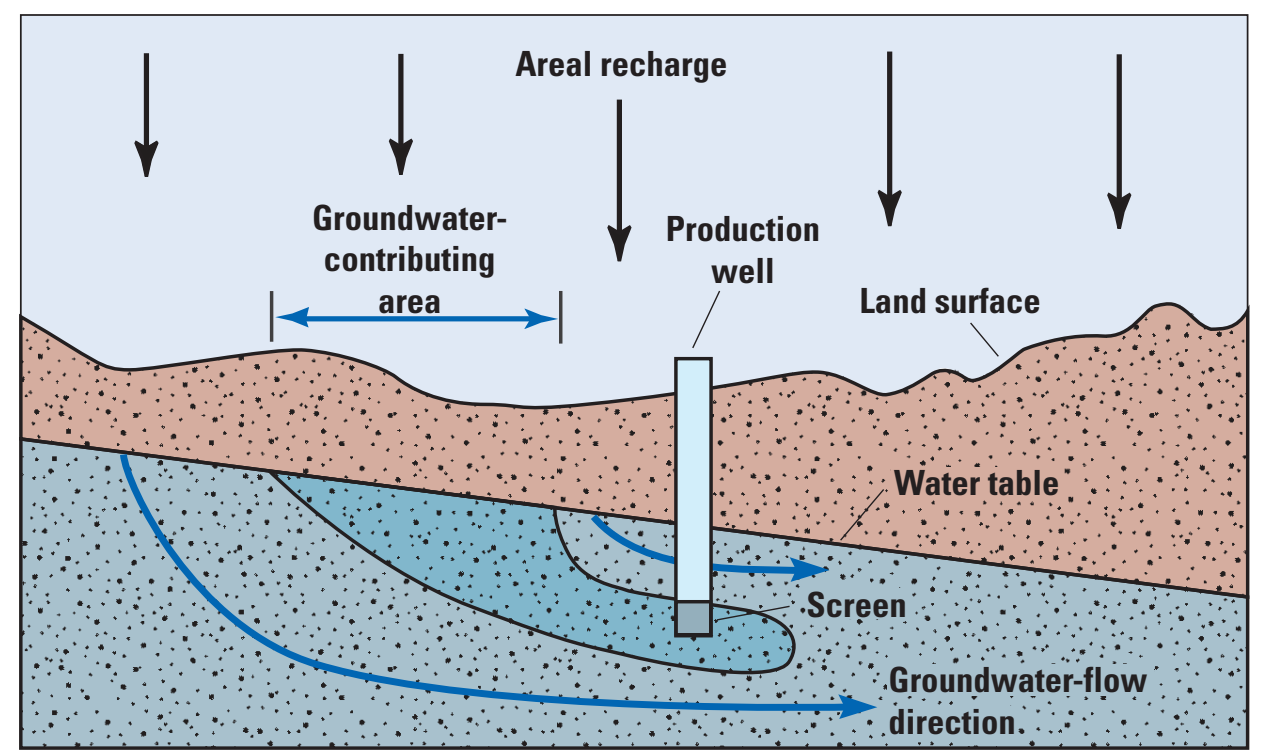

\section{B. Map View}

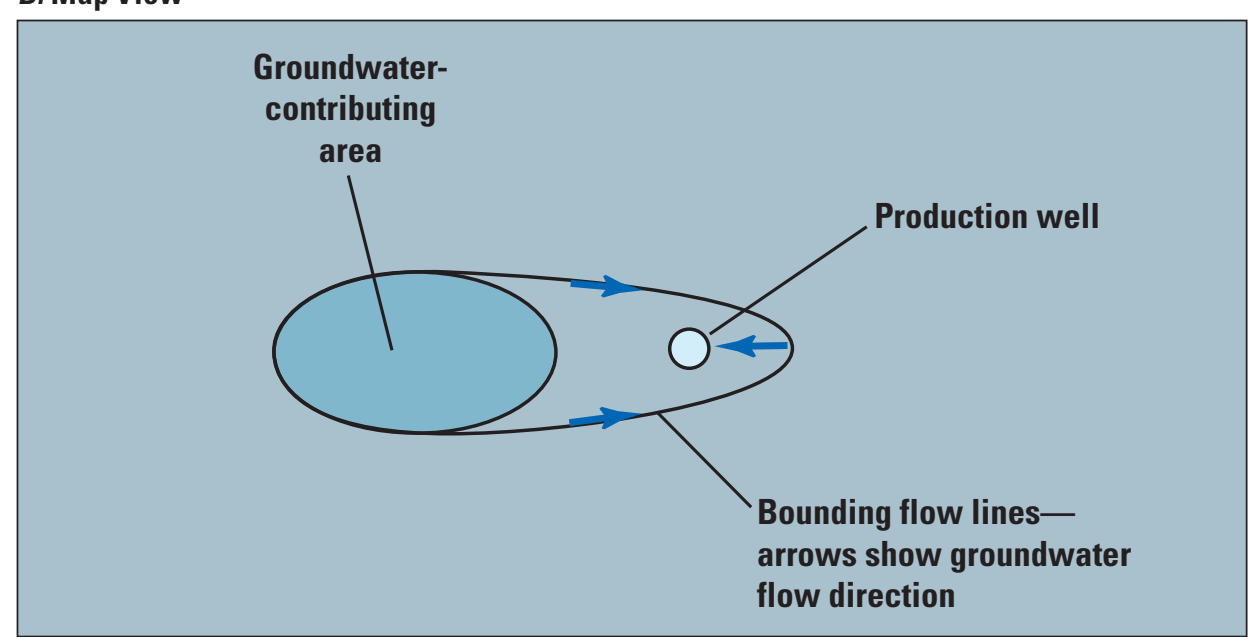

NOT TO SCALE

coastal water bodies, and production wells for simulated steady-state conditions.

The original documentation of each of the models provides detailed descriptions of the spatial discretization and layering of the models; hydrologic boundaries; hydraulic properties of the aquifers; hydrologic stresses; simulation of streams, ponds, and water use (withdrawals and wastewater return flows); calibration procedures; and model results and limitations.

\section{Development of Groundwater-Contributing Areas}

The concept of a contributing area, within which water enters the groundwater system at the water table as recharge, flows to a production well, and is removed from the aquifer as discharge (fig. 2), is well documented (Reilly and Pollock,
Figure 2. Groundwater-contributing area to a production well in a simplified hypothetical groundwater system showing $A$, cross-sectional view and $B$, map view (modified from Reilly and Pollock, 1993). These areas can appear to be disconnected from the well site in map view; their location and appearance depend on the production (pumping) rate, slope of the water table, and depth of the screen below the water table. 


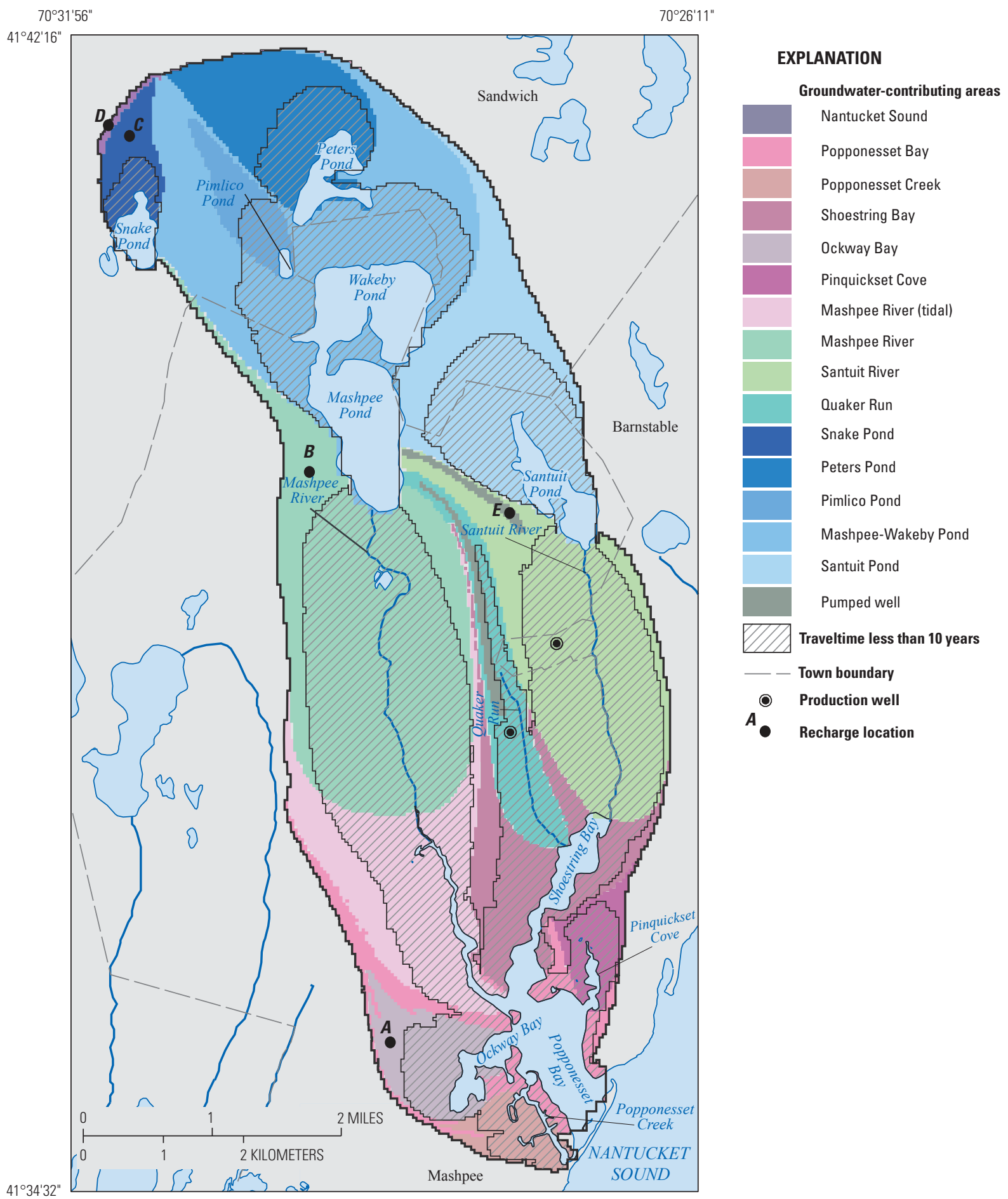

Figure 3. Groundwater-contributing areas to production wells, ponds, and coastal water bodies within the Popponesset Bay watershed (modified from Walter and others, 2004). The coastal water bodies receive most of their freshwater from surface-water inflows. Groundwater recharged near the coast (point A, for example) flows through shallow parts of the aquifer and discharges directly to coastal water bodies. Water recharged in the central part of the watershed (point B) discharges into streams that flow to coastal water bodies. In the upper part of the watershed, recharged water flows through one or more ponds before discharging to streams (point C). Some water recharging the aquifer near the northern edge of the watershed (point D) underflows the ponds and streams and discharges directly to the coast. Production wells remove some water from the watershed (point E). 
of groundwater mounds where groundwater flows radially outward toward the coast (for example, fig. 7 in Walter and Whealan, 2005). Because there is a strong downward component of flow near divides, water that recharges near the center of a groundwater mound travels deeper through the aquifer system than water that recharges near the coast. Therefore, for a given receptor, the closer the contributing area at the water table is to the top of a groundwater divide, the greater the vertical flow captured by the receptor because of the threedimensional nature of the flow system.

The recharge areas for ponds can be delineated in a manner similar to that for streams and coastal areas because the upgradient side of a pond acts as a groundwater discharge zone. Unlike the discharge into streams and coastal areas, however, water that discharges to a pond is not removed from the flow system but, instead, mixes within the pond and either passes through the downgradient side of the pond and reenters the aquifer or moves directly into outflowing streams. The water that reenters the aquifer is then available to move toward and discharge at production wells, streams, or coastal areas downgradient from the ponds.

Because water flows through ponds and reenters the aquifer, any production wells located downgradient from these ponds would receive some part of their total discharge from water that previously moved through ponds. For the purposes of this analysis, the contributing areas for wells are only the areas at the water table that directly contribute water to the wells; however, the influence of ponds on the source of water to production wells also should be considered (see Masterson and others [1998] for a detailed discussion of this concept).

The procedure used in this analysis to delineate groundwater-contributing areas was based on the methodology first documented in Barlow (1997) for delineating contributing areas for production wells on Cape Cod, which was subsequently used by Masterson and others (1998), Masterson and Walter (2000), and Walter and others (2004) for similar analyses. The analyses of Masterson and Walter (2000) and Walter and others (2004) also included the delineation of groundwater-contributing areas to other discharge locations, such as ponds, streams, and coastal water bodies.

The MODPATH particle-tracking model developed by Pollock (1994), which uses the heads and intercell flow rates (the flow rate at the face of each cell in the model) calculated by the MODFLOW model, was used to determine water particle pathlines and groundwater velocities. Starting locations of particles must be specified to initiate a particle-tracking analysis. Particles may be tracked either forward (from the water table to a discharge location) or backward (from a discharge location to the water table), but forward tracking has proven to be more reliable for delineating groundwater-contributing areas (Barlow, 1997). Detailed information on the use of particle tracking for the delineation of groundwater-contributing areas to discharge locations is provided in Masterson and others (1998), Masterson and Walter (2000), and Walter and others (2004).
The steady-state groundwater models for the PlymouthCarver region, the Sagamore (western) and Monomoy (eastern) flow lenses of Cape Cod, and lower Cape Cod were used to track particles forward in the direction of groundwater flow from the water table to discharge locations. In the MODPATH simulations, a single instantaneous release was specified of a two-dimensional four-by-four array of particles that were placed at the top face in each grid cell (each model grid cell was 400 feet on each side) in the model, and endpoints were recorded for the particles that terminated in a specific zone. "Zone" is a term used by MODPATH that refers to a hydrologic receptor for which a groundwater-contributing area will be delineated. In this analysis, the receptors of interest include streams, ponds, coastal water bodies, and production wells.

\section{Groundwater-Contributing Area Output}

The process of delineating groundwater-contributing areas produced a total of 1,155 individual shapefiles for the Plymouth-Carver region and Cape Cod model areas (table 1), which are included in Carlson and others (2017). The three main hydrologic receptors for which groundwater-contributing areas were delineated were ponds, streams, and coastal water bodies (estuaries). Additionally, groundwater-contributing areas for production wells were delineated for 88 wells in the Sagamore (western) flow lens model. In this model, each well was assigned a unique zone identification number, which resulted in 88 separate groundwater-contributing area shapefiles, one for each well. However, in the Plymouth-Carver region and Monomoy (eastern) Cape Cod models, all of the wells in the respective model area were assigned the same zone identification number. This resulted in one shapefile containing the groundwater-contributing areas for all of the wells in the model area. For most of the receptors, the groundwatercontributing areas were subdivided into two separate traveltime zones that represented areas where the traveltime from the water table to a given receptor was less than or equal to 10 years (lt10) and where traveltime was greater than 10 years (gt10). This division produced two separate contributing area zones for each receptor that, when combined, represent the entire groundwater-contributing area to that receptor.

Groundwater-contributing areas for the Plymouth-Carver region were grouped into three separate subfolders, one each for the Agawam-Wareham River, Duxbury-Kingston Bay, and Ellisville Harbor watersheds, containing 125, 137, and 9 separate groundwater-contributing areas, respectively (table 1). These groundwater-contributing areas were classified into two receptor types, "estuaries" and "ponds," both with "lt10" and "gt10" divisions, where "lt10" refers to areas where traveltime from the water table to the receptor was less than or equal to 10 years and "gt 10 " refers to areas where traveltime from the water table to the receptor exceeded 10 years. The "estuaries" type included stream, river, and estuary receptors. 
Table 1. Directory structure for simulated groundwater-contributing areas in Carlson and others (2017), Plymouth-Carver Region and Cape Cod, Massachusetts.

$[-$, indicates no subfolder $]$

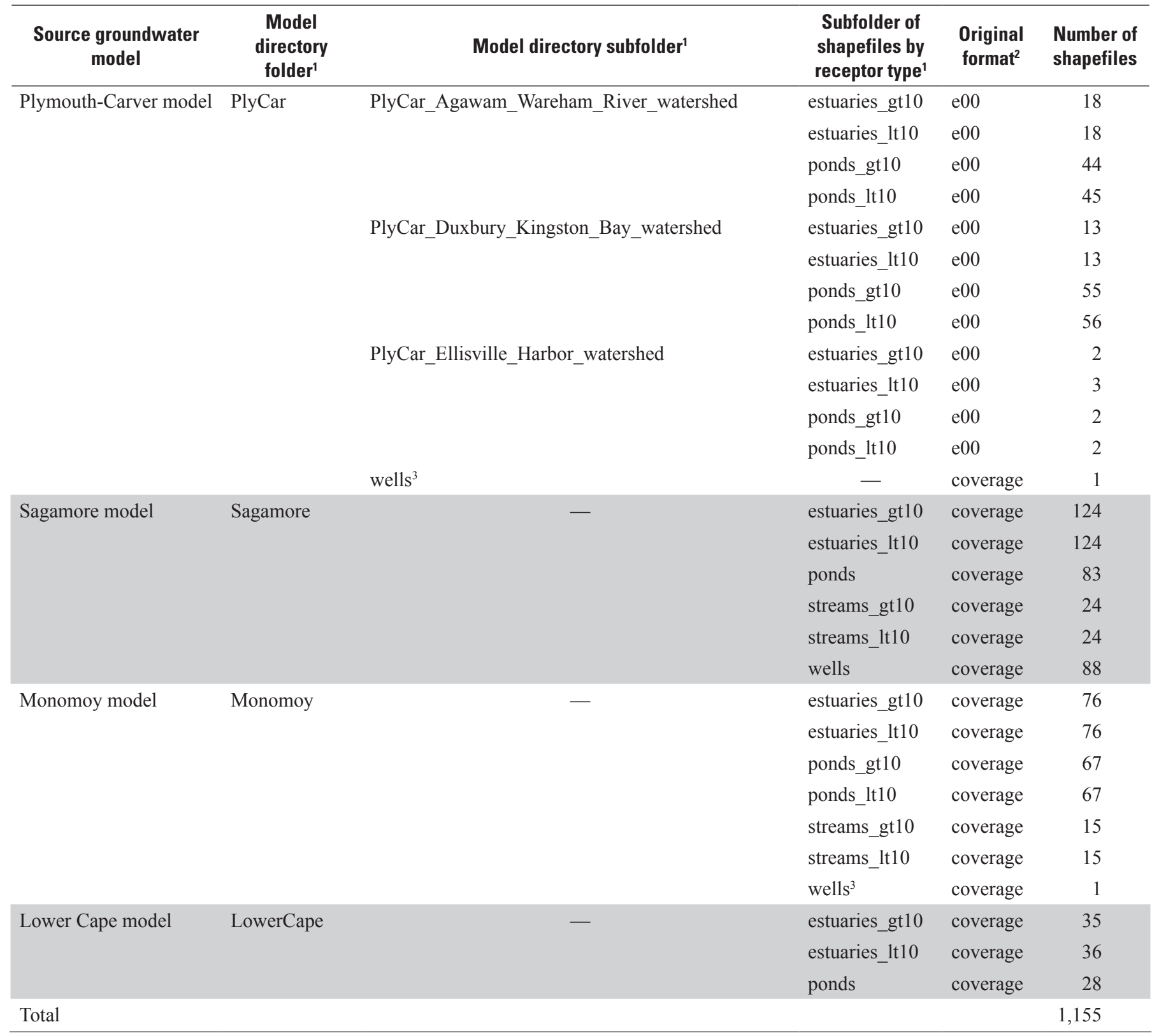

${ }^{1}$ Refers to associated directory structure for resulting shapefiles published in Carlson and others (2017). Subfolder of shapefiles by receptor type contains: estuaries, ponds, and streams; if present, "gt10" refers to areas where traveltime from the water table to the receptor exceeded 10 years; if present, "lt10" refers to areas where traveltime from the water table to the receptor was less than or equal to 10 years; gt10 and lt10 areas when combined represent the entire groundwater-contributing area to the receptor.

${ }^{2} \mathrm{e} 00$, ArcInfo interchange file; coverage, ArcInfo coverage.

${ }^{3}$ All combined. 
Groundwater-contributing areas for the Cape Cod model areas were not grouped into subfolders by watershed (table 1). There are a total of 379 contributing areas in the Sagamore model area, 316 in the Monomoy model area, and 99 in the lower Cape Cod model area. The Sagamore model had both 1t10 and gt10 divisions for groundwater-contributing areas for estuaries and streams, whereas ponds within the Sagamore model were not subdivided into two separate traveltime portions. The Monomoy model had both 1 t10 and gt10 divisions for estuaries, streams, and ponds. Also, groundwater-contributing areas in the lower Cape Cod model were only delineated for estuaries and ponds, with 1 t1 0 and gt10 divisions applied only to the estuaries.

In the Plymouth-Carver region and Cape Cod model areas, 25 receptors have no associated groundwater-contributing areas and appear as shapefiles with empty attribute tables. These receptors as represented in the models receive little or no simulated groundwater discharge and, therefore, receive no discharging particles. Particles entering the water table adjacent to these receptors instead discharge into nearby larger receptors and are part of those simulated groundwatercontributing areas.

Appendix 1 provides an overview of the conversion process from the original electronic format files to the shapefiles in Carlson and others (2017).

\section{Limitations}

Numerical models are useful tools for delineating groundwater-contributing areas in complex, three-dimensional flow systems such as in southeastern Massachusetts and Cape Cod. The groundwater-contributing areas described in this report, which were delineated by using the groundwater models for the Plymouth-Carver region (Masterson and others, 2009), the Sagamore (western) and Monomoy (eastern) flow lenses of Cape Cod (Walter and Whealan, 2005), and lower Cape Cod (Masterson, 2004), are valid only for the specific water use and recharge conditions used in those analyses. If water use and recharge conditions change in the future, the groundwatercontributing areas to ponds, streams, coastal water bodies, and production wells in the Plymouth-Carver region and Cape Cod would need to be reevaluated. Groundwater-contributing areas also are subject to the limitations of simulating groundwater flow at the regional scales as detailed in the original modeldocumentation reports.

\section{References Cited}

Barlow, P.M., 1997, Particle-tracking analysis of contributing areas of public-supply wells in simple and complex flow systems, Cape Cod, Massachusetts: U.S. Geological Survey Water-Supply Paper 2434, 66 p. [Also available at https://pubs.er.usgs.gov/publication/ofr93159.]

Carlson, C.S., Masterson, J.P., Walter, D.A., and Barbaro, J.R., 2017, Simulated groundwater-contributing areas to selected streams, ponds, coastal water bodies, and production wells, Plymouth-Carver region and Cape Cod, Massachusetts: U.S. Geological Survey data release, accessed December 2017 at https://doi.org/10.5066/F7V69H2Z.

Harbaugh, A.W., 2005, MODFLOW-2005, the U.S. Geological Survey modular ground-water model-The groundwater flow process: U.S. Geological Survey Techniques and Methods, book 6, chap. A16, [variously paged]. [Also available at https://pubs.er.usgs.gov/publication/tm6A16.]

Harbaugh, A.W., Banta, E.R., Hill, M.C., and McDonald, M.G., 2000, MODFLOW-2000, the U.S. Geological Survey modular groundwater model-User guide to modularization concepts and the groundwater flow process: U.S. Geological Survey Open-File Report 2000-92, 121 p. [Also available at https://pubs.er.usgs.gov/publication/ofr200092.]

Masterson, J.P., 2004, Simulated interaction between freshwater and saltwater and effects of ground-water pumping and sea-level change, Lower Cape Cod aquifer system, Massachusetts: U.S. Geological Survey Scientific Investigations Report 2004-5014, 78 p. [Also available at https://pubs.er.usgs.gov/publication/sir20045014.]

Masterson, J.P., Carlson, C.S., and Walter, D.A., 2009, Hydrogeology and simulation of groundwater flow in the Plymouth-Carver-Kingston-Duxbury aquifer system, southeastern Massachusetts: U.S. Geological Survey Scientific Investigations Report 2009-5063, 110 p. [Also available at https://pubs.er.usgs.gov/publication/sir20095063.]

Masterson, J.P., and Walter, D.A., 2000, Delineation of ground-water recharge areas, western Cape Cod, Massachusetts: U.S. Geological Survey Water-Resources Investigation Report 2000-4000, 1 sheet. [Also available at https://pubs.er.usgs.gov/publication/wri004000.] 
Masterson, J.P., Walter, D.A., and LeBlanc, D.R., 1998, Delineation of contributing areas to selected public-supply wells, western Cape Cod, Massachusetts: U.S. Geological Survey Water-Resources Investigations Report 98-4237, 45 p. [Also available at https://pubs.er.usgs.gov/publication/ wri984237.]

Pollock, D.W., 1994, User's guide for MODPATH/MODPATH-PLOT, version 3; a particle tracking post-processing package for MODFLOW, the U.S. Geological Survey finitedifference groundwater flow model: U.S. Geological Survey Open-File Report 94-464, 234 p. [Also available at https://pubs.er.usgs.gov/publication/ofr94464.]

Reilly, T.E., and Pollock, D.W., 1993, Factors affecting areas contributing recharge to wells in shallow aquifers: U.S. Geological Survey Water-Supply Paper 2412, 21 p. [Also available at https://pubs.er.usgs.gov/publication/ wsp2412.]
Walter, D.A., Masterson, J.P., and Hess, K.M., 2004, Groundwater recharge areas and traveltimes to pumped wells, ponds, streams, and coastal water bodies, Cape Cod, Massachusetts: U.S. Geological Survey Scientific Investigations Map I-2857, 1 sheet. [Also available at https://pubs.er.usgs.gov/publication/sim2857.]

Walter, D.A., and Whealan, A.T., 2005, Simulated water sources and effects of pumping on surface and ground water, Sagamore and Monomoy flow lenses, Cape Cod, Massachusetts: U.S. Geological Survey Scientific Investigations Report 2004-5181, 85 p. [Also available at https://pubs.er.usgs.gov/publication/sir20045181.] 


\section{Appendix 1. Conversion Process from Original Electronic Format Files to Shapefiles}

The original, simulated groundwater-contributing areas were in the form of ArcInfo interchange files (.e00) for the Plymouth-Carver region model and ArcInfo coverages for the Cape Cod models. The original electronic format files were converted to current-format shapefiles and organized by model area as outlined in table 1 .

Files in their original format were converted to shapefiles by using ArcPy (Price, 2017) in a Jupyter Notebook (Pérez and Granger, 2007) with the programming language Python (https://www.python.org/). Conversion of the groundwater-contributing areas for the PlymouthCarver region model needed an extra step to first import from the .e00 format to a coverage format through use of the "ImportFromE00_conversion" feature. Once in coverage format, files from all model areas were converted to shapefiles by using the "FeatureClassToFeatureClass_conversion" feature. Additional unnecessary fields were automatically added during the conversion from .e00, and these were removed. In addition to the existing "AREA" and "PERIMETER" fields in the data table, one new field called "Name" that contained the name of each groundwater-contributing area was added to the data table for each shapefile.

To make the filename for each shapefile as useful as possible, additional information was included, such as the original .e00 or coverage name (for comparison to the files previously supplied), the name of model area, the receptor type and whether or not it was a divided zone for lt10 or gt10, and the name of the groundwater-contributing area (same as that added to the new field "Name"). The original .e00 and coverage name included a code, and the code and receptor name appeared in a lookup table. These original codes and corresponding groundwater-contributing area names are listed in table 1-1. An ArcMap project (USGS_original_contributing_areas_PlyCar_CapeCod_shapefiles.mxd) that contains all of the groundwater-contributing area shapefiles for the Plymouth-Carver region and Cape Cod model areas is included in Carlson and others (2017).

\section{References Cited}

Pérez, Fernando, and Granger, B.E., 2007, IPython-A system for interactive scientific computing: Computing in Science and Engineering, v. 9, no. 3, p. 21-29. [Also available at https://doi.org/10.1109/MCSE.2007.53.]

Price, C.V., 2017, Using Anaconda modules from the ESRI python environment: U.S. Geological Survey web page, accessed March 6, 2017, at https://my.usgs.gov/confluence/display/

EGIS/Using + Anaconda + modules + from + the + ESRI + python+environment. 
Table 1-1. Original codes and corresponding names of the groundwater-contributing areas for the groundwater models of the Plymouth-Carver region and Cape Cod, Massachusetts.

[Codes are distinguished by model area and receptor type, followed by a decoded example of an original filename for that model and receptor type]

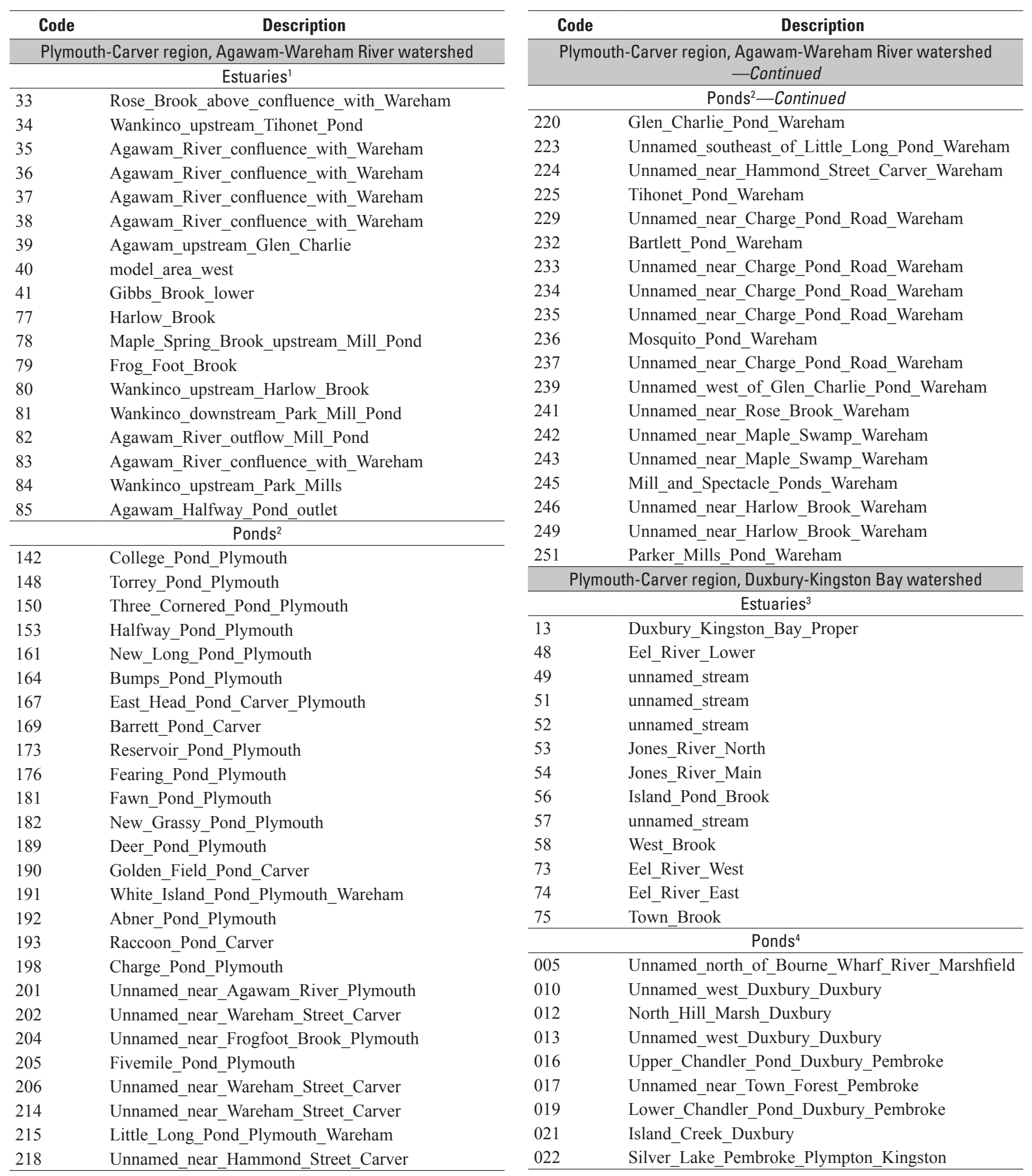


Table 1-1. Original codes and corresponding names of the groundwater-contributing areas for the groundwater models of the Plymouth-Carver region and Cape Cod, Massachusetts.-Continued

[Codes are distinguished by model area and receptor type, followed by a decoded example of an original filename for that model and receptor type]

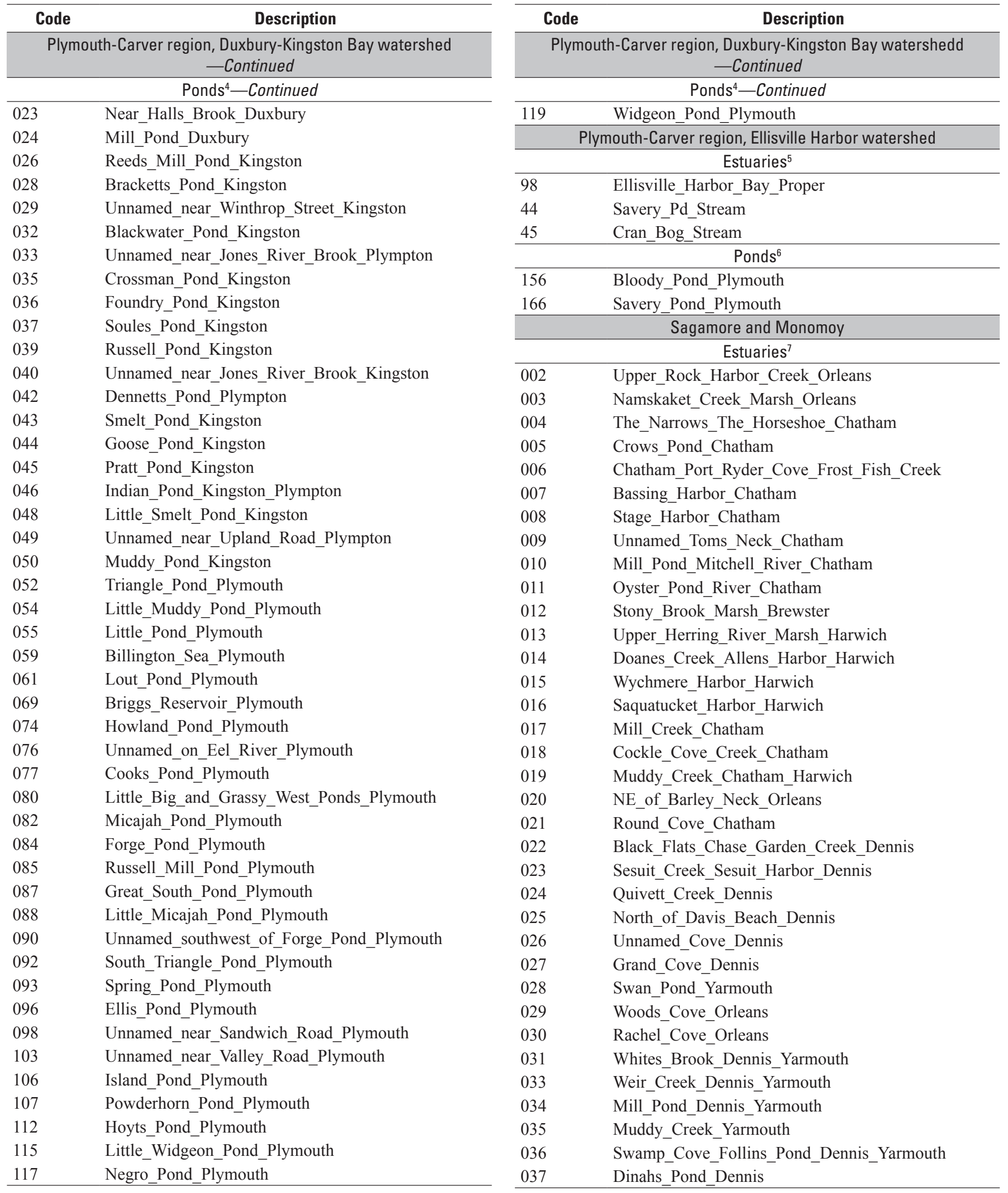


Table 1-1. Original codes and corresponding names of the groundwater-contributing areas for the groundwater models of the Plymouth-Carver region and Cape Cod, Massachusetts.-Continued

[Codes are distinguished by model area and receptor type, followed by a decoded example of an original filename for that model and receptor type]

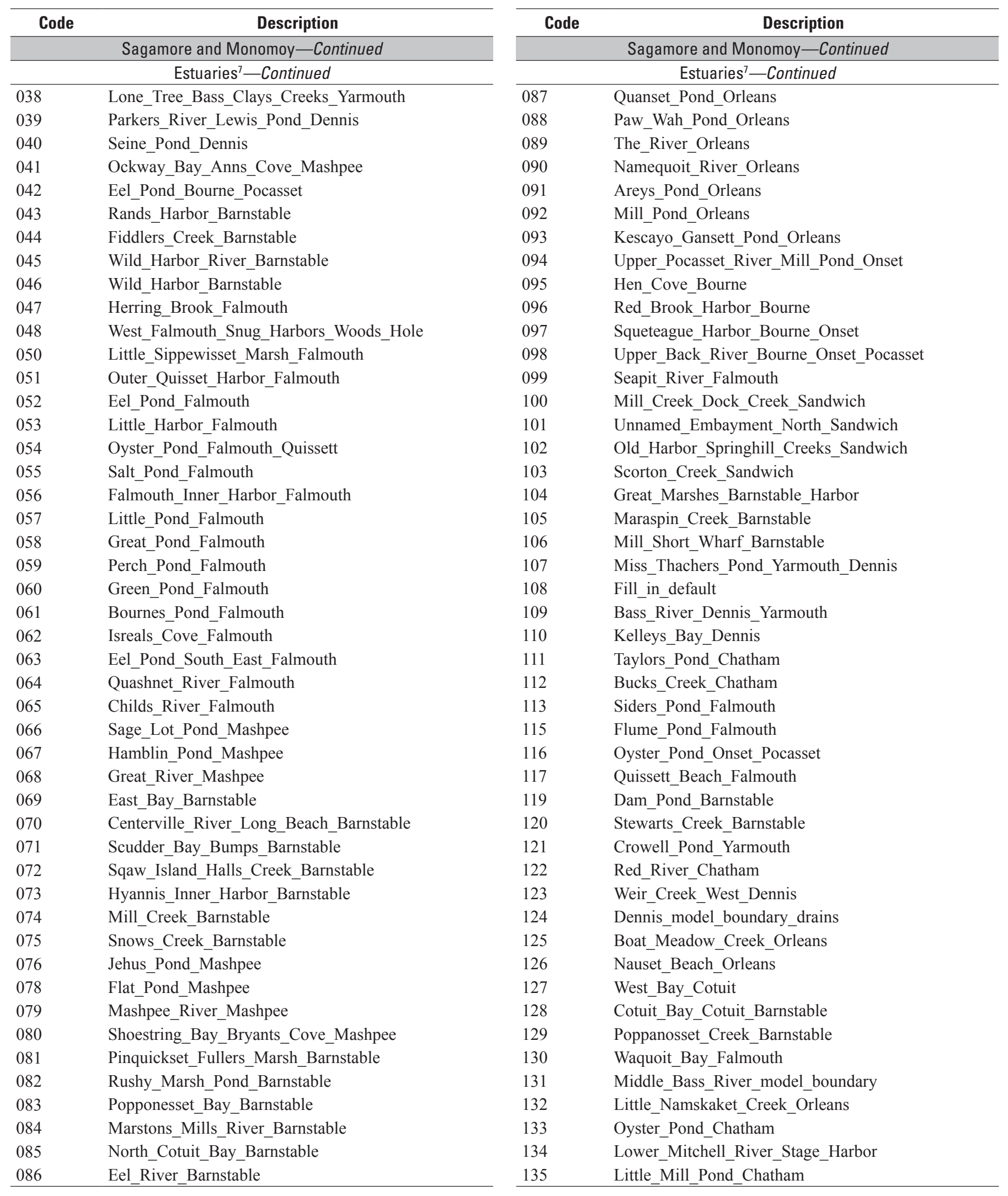


Table 1-1. Original codes and corresponding names of the groundwater-contributing areas for the groundwater models of the Plymouth-Carver region and Cape Cod, Massachusetts.-Continued

[Codes are distinguished by model area and receptor type, followed by a decoded example of an original filename for that model and receptor type]

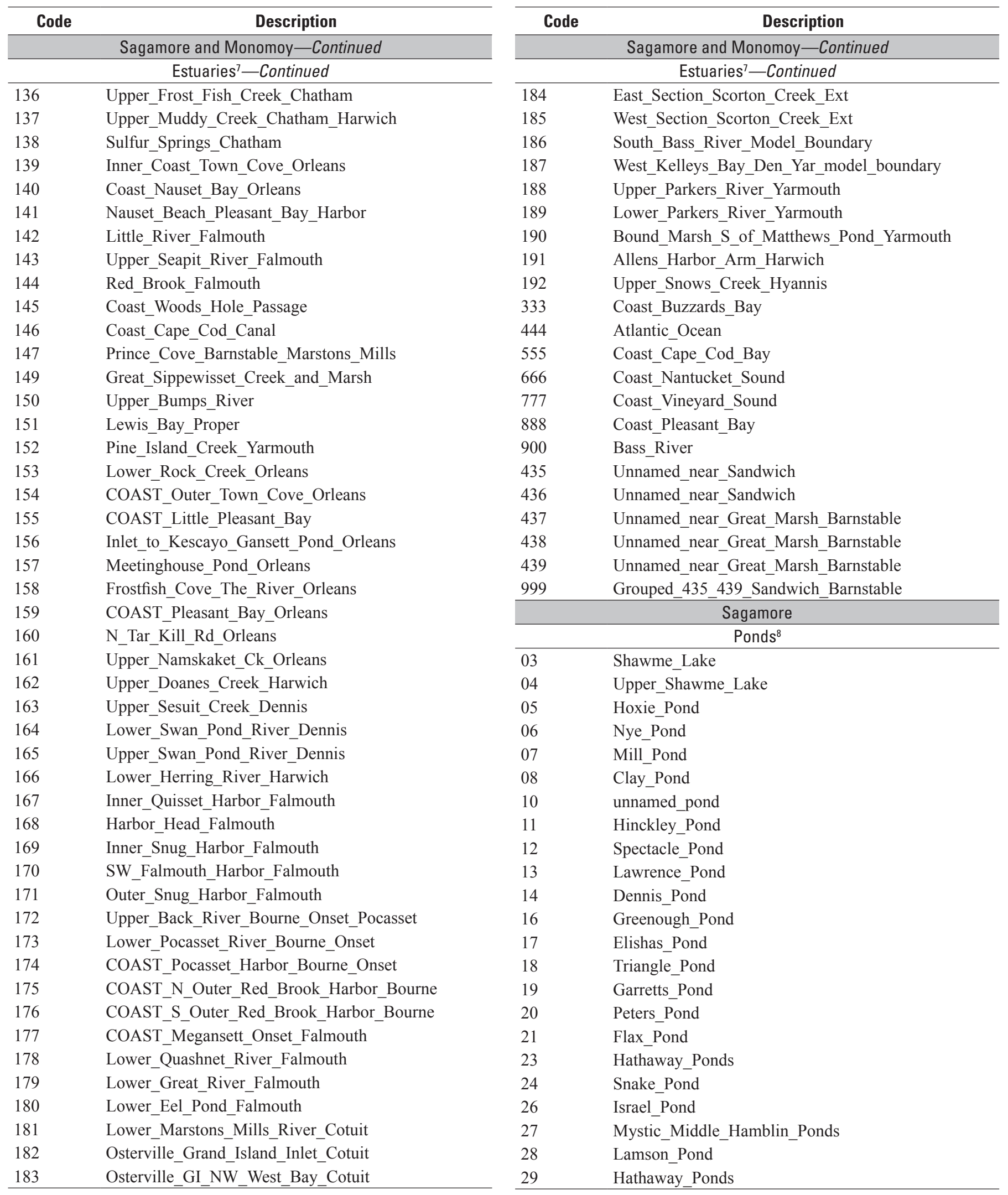


Table 1-1. Original codes and corresponding names of the groundwater-contributing areas for the groundwater models of the Plymouth-Carver region and Cape Cod, Massachusetts.-Continued

[Codes are distinguished by model area and receptor type, followed by a decoded example of an original filename for that model and receptor type]

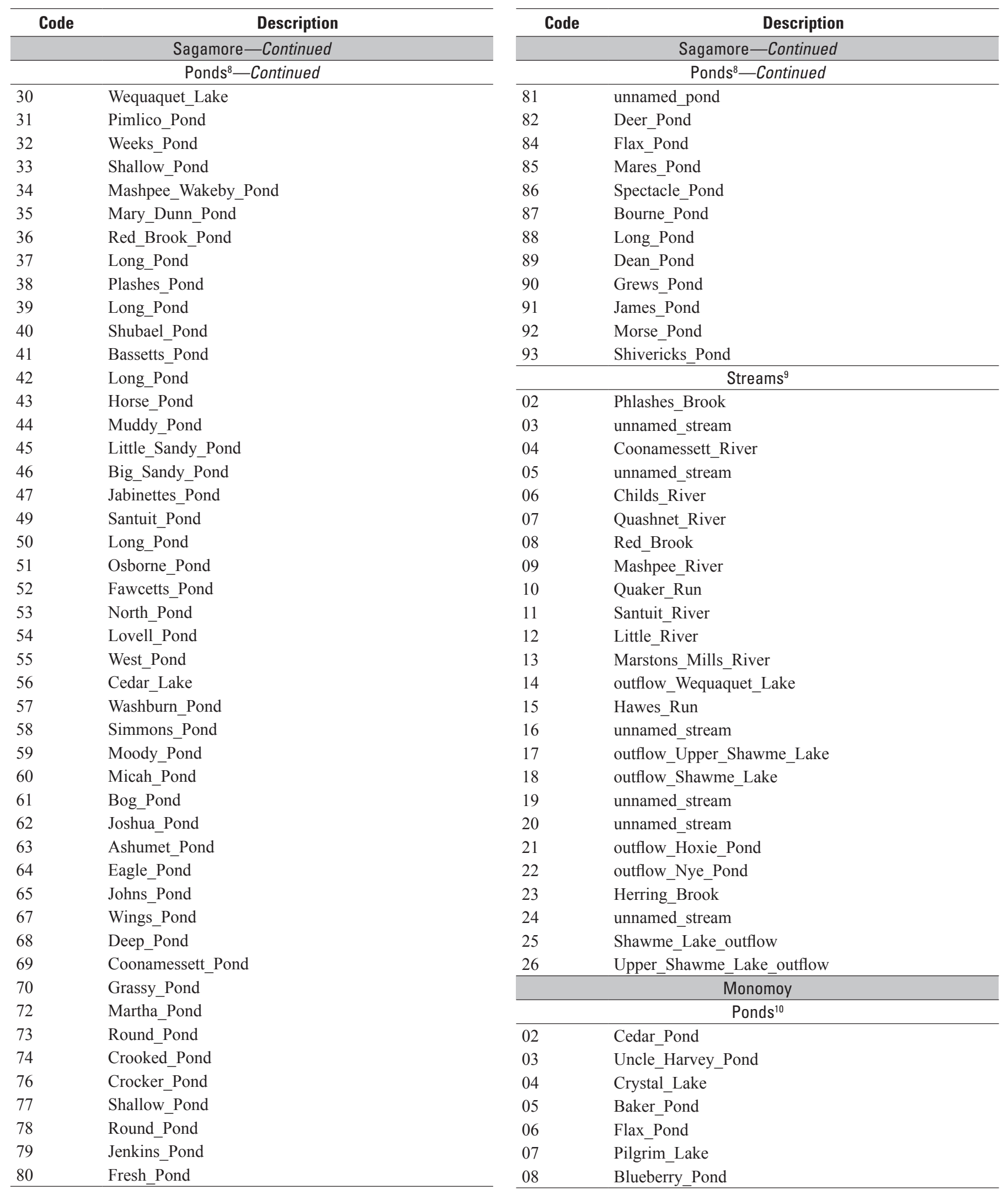


Table 1-1. Original codes and corresponding names of the groundwater-contributing areas for the groundwater models of the Plymouth-Carver region and Cape Cod, Massachusetts.-Continued

[Codes are distinguished by model area and receptor type, followed by a decoded example of an original filename for that model and receptor type]

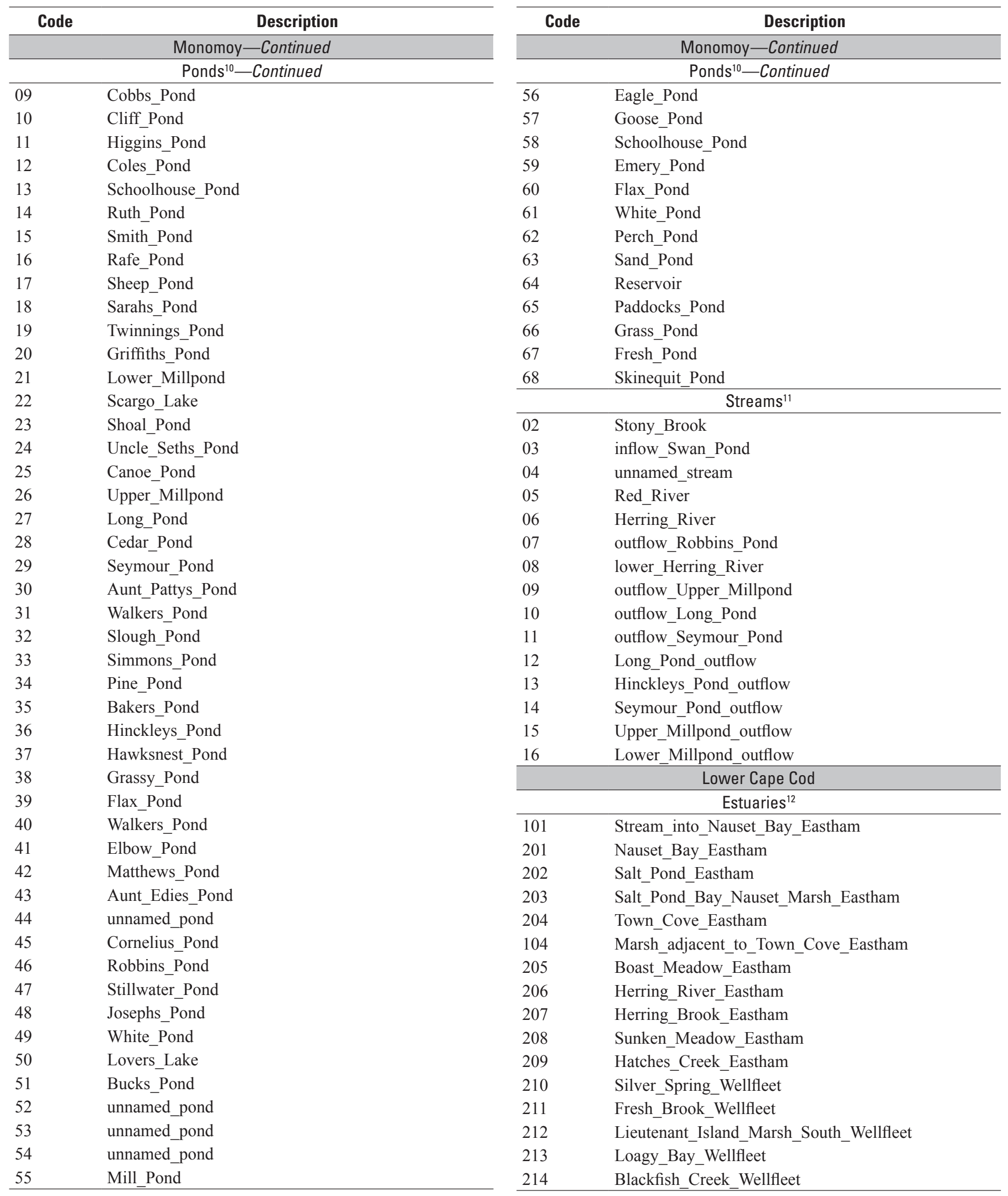


Table 1-1. Original codes and corresponding names of the groundwater-contributing areas for the groundwater models of the Plymouth-Carver region and Cape Cod, Massachusetts.-Continued

[Codes are distinguished by model area and receptor type, followed by a decoded example of an original filename for that model and receptor type]

\begin{tabular}{|c|c|}
\hline Code & Description \\
\hline \multicolumn{2}{|r|}{ Lower Cape Cod-Continued } \\
\hline \multicolumn{2}{|r|}{ Estuaries ${ }^{12}$-Continued } \\
\hline 215 & Drummer_Cove_Wellfleet \\
\hline 216 & Wellfleet_Harbor_Wellfleet \\
\hline 217 & The_Cove_Wellfleet \\
\hline 218 & Pilgrim_Spring_1_Wellfleet \\
\hline 219 & Pilgrim_Spring_2_Wellfleet \\
\hline 220 & Duck_Creek_Wellfleet \\
\hline 221 & Wellfleet_Creek_Wellfleet \\
\hline 222 & Herring_River_Wellfleet \\
\hline 223 & Mouth_of_Herring_River_Wellfleet \\
\hline 224 & Pamet_Harbor_Truro \\
\hline 225 & Mill_Creek_Truro \\
\hline 226 & Lower_Pamet_River_Truro \\
\hline 227 & Upper_Pamet_River_Truro \\
\hline 228 & Little_Pamet_River_Truro \\
\hline 229 & Great_Swamp_Truro \\
\hline 230 & Village_Pond_Truro \\
\hline 231 & Pilgrim_Lake_Truro \\
\hline 232 & Provincetown_Harbor_Provincetown \\
\hline 233 & Great_Marsh_Provincetown \\
\hline 234 & Hatches_Harbor_Provincetown \\
\hline \multicolumn{2}{|r|}{ Ponds $^{13}$} \\
\hline 235 & Herring_Pond_Eastham \\
\hline 237 & Mill_Pond_Eastham \\
\hline 238 & Jemina_Pond_Eastham \\
\hline 239 & Depot_Pond_Eastham \\
\hline 241 & Great_Pond_Eastham \\
\hline 243 & Widow_Harding_Eastham \\
\hline 244 & Minister_Pond_Eastham \\
\hline 245 & Duck_Pond_Wellfleet \\
\hline 247 & Great_Pond_Wellfleet \\
\hline 249 & Dyer_Pond_Wellfleet \\
\hline 251 & Long_Pond_Wellfleet \\
\hline 253 & Gull_Pond_Wellfleet \\
\hline 256 & Higgins_Pond_Wellfleet \\
\hline 258 & Herring_Pond_Wellfleet \\
\hline 259 & Willam_Pond_Wellfleet \\
\hline 260 & Slough_Pond_Wellfleet \\
\hline 262 & Horseleech_Pond_Wellfleet \\
\hline 264 & Round_Pond_Wellfleet \\
\hline 265 & Great_Pond_Truro \\
\hline 267 & Snow_Pond_Truro \\
\hline 268 & Ryder_Pond_Truro \\
\hline 269 & Great_Pond_Provincetown \\
\hline 270 & Bennett_Pond_Provincetown \\
\hline 271 & Duck_Pond_Provincetown \\
\hline 272 & Clapps_Pond_Provincetown \\
\hline 273 & Shank_Painter_Pond_1_Provincetown \\
\hline
\end{tabular}

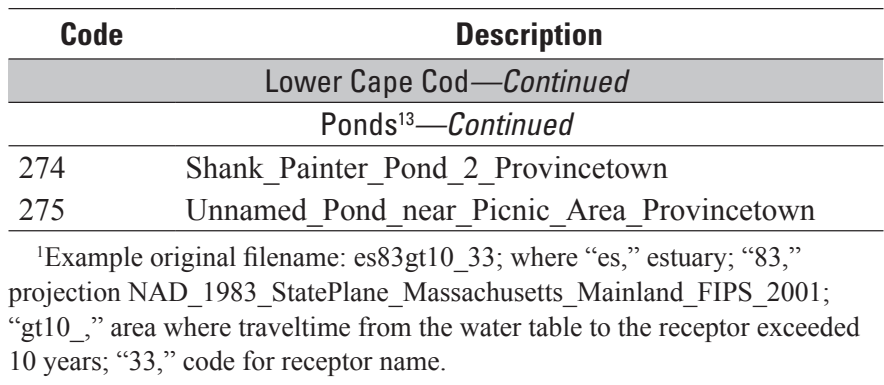

${ }^{2}$ Example original filename: 83gt10_142; "83," projection NAD_1983_ StatePlane_Massachusetts_Mainland_FIPS_2001; “gt10_,"area where traveltime from the water table to the receptor exceeded 10 years; "142," code for receptor name.

${ }^{3}$ Example original filename: es83gt10_13; where "es," estuary; "83," projection NAD 1983 StatePlane Massachusetts Mainland FIPS 2001; "gt10_," area where traveltime from the water table to the receptor exceeded 10 years; "13," code for receptor name.

${ }^{4}$ Example original filename: 83gt10_5; "83," projection NAD_1983 StatePlane_Massachusetts_Mainland_FIPS_2001; "gt10_," area where traveltime from the water table to the receptor exceeded 10 years; " 5 ," code for receptor name, with zero(s) added as placeholder to left of code digit.

${ }^{5}$ Example original filename: es83gt10_44; where "es," estuary; "83," projection NAD_1983_StatePlane_Massachusetts_Mainland_FIPS_2001; "gt10_," area where traveltime from the water table to the receptor exceeded 10 years; "44," code for receptor name.

${ }^{6}$ Example original filename: 83gt10_156; " 83 ," projection NAD_1983_ StatePlane_Massachusetts_Mainland_FIPS_2001; "gt10_," area where traveltime from the water table to the receptor exceeded 10 years; "156," code for receptor name.

${ }^{7}$ Example original filename: em02283gt10e; where "em," estuary; "022," code for receptor name, with zero(s) added as place holder to left of code digit; "83," projection NAD_1983_StatePlane_Massachusetts_Mainland_ FIPS_2001; "gt10e," area where traveltime from the water table to the receptor exceeded 10 years.

${ }^{8}$ Example original filename: pd0883e; where "pd," pond; "08," code for receptor name, with zero added as place holder to left of code digit; "83e," projection NAD_1983_StatePlane_Massachusetts_Mainland_FIPS_2001.

${ }^{9}$ Example original filename: st0283gt10e; where "st," stream; " 02 ," code for receptor name, with zero added as place holder to left of code digit; "83," projection NAD_1983_StatePlane_Massachusetts_Mainland_FIPS_2001; "gt10e," area where traveltime from the water table to the receptor exceeded 10 years. 
${ }^{10}$ Example original filename: pd0283gt10e; where "pd," pond; "02," code for receptor name, with zero added as place holder to left of code digit; "83," projection NAD_1983_StatePlane_Massachusetts_Mainland_FIPS_2001;

"gt10e," area where traveltime from the water table to the receptor exceeded 10 years.

${ }^{11}$ Example original filename: st0283gt10e; where "st," stream; "02," code for receptor name, with zero added as place holder to left of code digit; "83," projection NAD_1983_StatePlane_Massachusetts_Mainland_FIPS_2001; "gt10e," area where traveltime from the water table to the receptor exceeded 10 years.

${ }^{12}$ Example original filename: em10483gt10e; where "em," estuary; "104," code for receptor name; "83," projection NAD_1983_StatePlane_Massachusetts_Mainland_FIPS_2001; "gt10e," area where traveltime from the water table to the receptor exceeded 10 years.

${ }^{13}$ Example original filename: em24183p2; where "em," estuary contributing area; "241," code for receptor name; "83," projection NAD_1983_StatePlane_ Massachusetts_Mainland_FIPS_2001; “p2,”pond. 

For more information about this report, contact: Director, New England Water Science Center U.S. Geological Survey

10 Bearfoot Road

Northborough, MA 01532

dc_nweng@usgs.gov

or visit our website at

https://newengland.water.usgs.gov

Publishing support provided by the Pembroke Publishing Service Center 


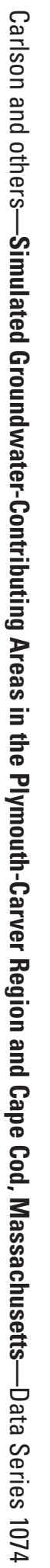

